\begin{tabular}{|c|c|c|c|c|c|c|}
\hline \multirow{3}{*}{$\begin{array}{l}\text { 2. ECN Category (mark one) } \\
\text { Supplemental } \\
\text { Direct Revision } \\
\text { Change ECN } \\
\text { Temporary } \\
\text { Standby } \\
\text { Supersedure } \\
\text { CancelWoid }\end{array}$} & \multicolumn{3}{|c|}{$\begin{array}{l}\text { 3. Originator's Name, Organization, MSIN, and Telephone No. } \\
\text { Ronald L. Nelson, CHG, H6-18, 372-1452 }\end{array}$} & 4. & $\begin{array}{l}\text { JSQ Required? } \\
\text { Yes } \quad \text { No }\end{array}$ & \multirow{2}{*}{\begin{tabular}{|l|} 
5. Date \\
$06 / 05 / 00$ \\
8. Approval Designator
\end{tabular}} \\
\hline & \multicolumn{2}{|c|}{$\begin{array}{l}\text { 6. Project Title/No. Work Order No. } \\
\text { CHG IRM Strategic Pln }\end{array}$} & \multicolumn{3}{|c|}{ 7. Bldg./Sys./Fac. No. } & \\
\hline & \multicolumn{2}{|c|}{$\begin{array}{l}\text { 9. Document Numbers Changed by this ECN (includes } \\
\text { sheet no. and rev.) }\end{array}$} & \multicolumn{3}{|c|}{ 10. Related ECN No(s). } & $\begin{array}{l}\text { 11. Related PO No. } \\
\text { N/A }\end{array}$ \\
\hline $\begin{array}{l}\text { 12a. Modification Work } \\
\square \text { Yes (fill out Blk. 12b) } \\
\square \text { No (NA Blks. 12b, } \\
\text { (2c, 12d) }\end{array}$ & $\begin{array}{l}\text { 12b. Work Package No. } \\
\text { N/A }\end{array}$ & $\begin{array}{l}\text { 12c. Modification Work Co } \\
\text { N/A } \\
\text { Design Authority/Cog. En }\end{array}$ & eted & & $\begin{array}{l}\begin{array}{l}\text { 12d. Restored } \\
\text { or Stand }\end{array} \\
\frac{\mathrm{N} / \mathrm{A}}{\text { Design Autho }}\end{array}$ & $\begin{array}{l}\text { Original Condition (Temp. } \\
\text { ECNs only) } \\
\text { ty/Cog. Engineer Signature \& } \\
\text { Date }\end{array}$ \\
\hline
\end{tabular}

13a. Description of Change

13b. Design Baseline Document? $\square$ Yes $\bigotimes$ No

Throughout the document, removed undefinable "all".

Page 2, Change Privatization Contractor to waste Treatement Contractor

14a. Justification (mark one)
Criteria Change
Design Improvement
Environmental
Facility Deactivation
As-Found
Facilitate Const.
Const. Error/Omission
Design Error/Omission

15. Distribution (include name, MSIN, and no. of copies)

Adamson, Kevin B. H6-11

Alexander, Donald H. H6-60

Burgde, Larry F. L5-66

Ebben, Michael D. H6-11

McClusky, Jim K. H6-61

Nelson, Ronald L. H6-18
Taylor Terry D. H6-64

Wacek Hal J. H6-60

Central Files B1-53

DOE Reading RoomH2-53
RELEASE STAMP

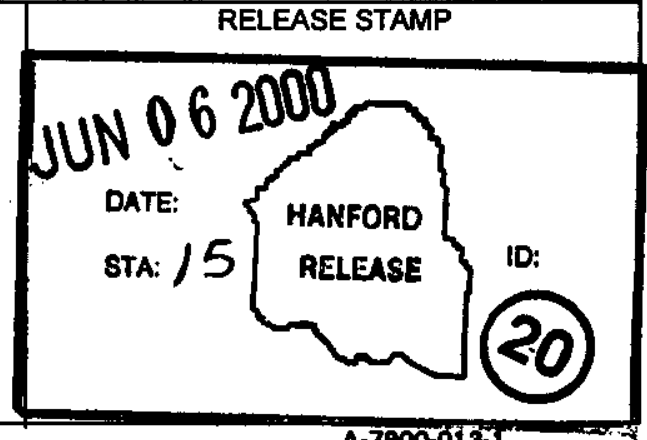

A-7600-013 


\section{ENGINEERING CHANGE NOTICE}

16. Design Verfication Required

\section{$\square$ Yes \\ No}

17. Cost Impact

ENGINEERING

Additional $\square$

$\$$

$\$$
Page 2 of 2 CONSTRUCTION

$\$$

Additional

Savings
$\$$
1. ECN (use no. from pg. 1) 650246 yea $6 / 6$

18. Schedule Impact (days)

Improvement

Delay

19. Change Impact Review: Indicate the related documents (other than the engineering documents identified on Side 1) that will be affected by the change described in Block 13 . Enter the affected document number in Block 20 .

\section{SDD/DD}

Functional Design Criteria

Operating Specification

Criticality Specification

Conceptual Design Report

Equipment Spec.

Const. Spec.

Procurement Spec.

Vendor Information

OM Manual

FSAR/SAR

Safety Equipment List

Radiation Work Permit

Environmental Impact Statement

Environmental Report

Environmental Permit

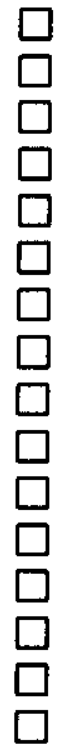

Seismic/Stress Analysis

Stress/Design Report

Interface Control Drawing

Calibration Procedure

Installation Procedure

Maintenance Procedure

Engineering Procedure

Operating Instruction

Operating Procedure

Operational Safety Requirement

IEFD Drawing

Cell Arrangement Drawing

Essential Material Specification

Fac. Proc. Samp. Schedule

Inspection Plan

Inventory Adjustment Request $\square$
$\square$
$\square$
$\square$
$\square$
$\square$
$\square$
$\square$
$\square$
$\square$
$\square$
$\square$
$\square$
$\square$
Tank Calibration Manual Health Physics Procedure Spares Multiple Unit Listing Test Procedures/Specification Component Index ASME Coded Item Human Factor Consideration Computer Software Electric Circuit Schedule ICRS Procedure Process Control Manual/Plan Process Flow Chart

Purchase Requisition

Tickler File

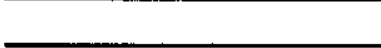

20. Other Affected Documents: (NOTE: Documents listed below will not be revised by this ECN.) Signatures below indicate that the signing organization has been notified of other affected documents listed below.

Document Number/Revision Document Number/Revision

Document Number/Revision

$\mathrm{N} / \mathrm{A}$

21. Approvals

Signature

Date

Design Authority

Cog. Eng. Ronald L Nelson

QA

Safety

Environ.

Other
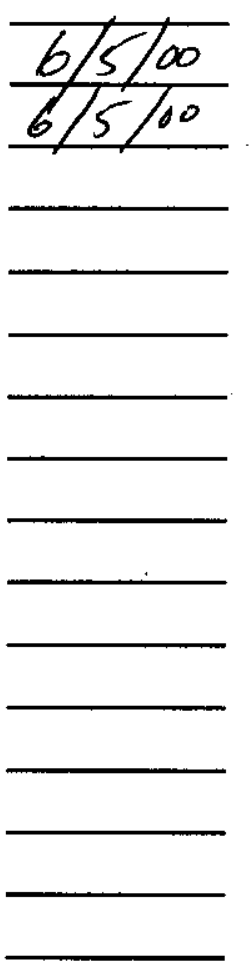

Signature

Date

Design Agent

PE

QA

Safety

Design

Environ.

Other

\section{DEPARTMENT OF ENERGY}

Signature or a Control Number that tracks the Approval Signature

ADDITIONAL 


\title{
CH2M HILL Hanford Group, Inc. (CHG) Information Resource Management (IRM) Strategic Plan
}

\author{
Ronald I. Nelson \\ CH2M HILL Hanford Group, Inc. \\ Richland, WA 99352 \\ U.S. Department of Energy Contract DE-AC06-99RL14047 \\ EDT/ECN: 650246 \\ UC: 2000 \\ Cost Center: 72900 \\ Charge Code: HMLM0441 110702/AJ10 \\ B\&R Code: \\ $\mathrm{N} / \mathrm{A}$ \\ Total Pages: \\ 29 \\ Key Words: CHG IRM Strategic Plan, Information Architecture
}

\begin{abstract}
The CH2M HILL Hanford Group, Inc., Information Resource Management Strategic Plan is the top-level planning document for applying information and information resource management to achieve the CHG mission for the management of the River Protection Project waste tank farm.
\end{abstract}

TRADEMARK DISCLAIMER. Reference herein to any specific commercial product, process, or service by trade name, trademark, manufacturer, or otherwise, does not necesearily constitute or imply its endorsement, recommendation, or favoring by the United States Government or any agency thereof or its contractors or subcontractors.

Printed in the United States of America. To obtain copies of this document, contact: Document Control Services, P.O. Box 950, Malletop H6-08, Richland WA 99352, Phone (509) 372-2420; Fax (509) 376-4989.
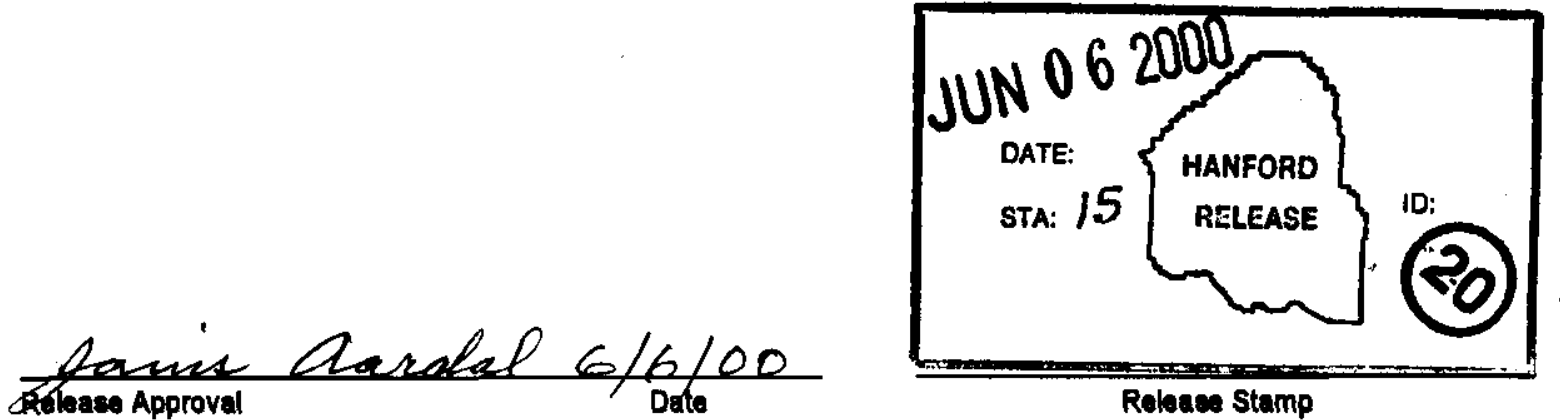

Releace Stamp 


\section{RECORD OF REVISION}

(1) Document Number RPP-6212, Rev 1

(2) Title

CH2M HILL Hanford Group, Inc. Information Resource Management Strategic Plan

Change Control Record

(3) Revision

0

1
(4) Description of Change - Replace, Add, and Delete Pages

(7) EDT-628610, 5/8/2000

Fis Replace, per ECN-650246
Authorized for Release

\begin{tabular}{l|ll} 
(5) Cog. Engr. & (6) Cog. Mgr. Date
\end{tabular}

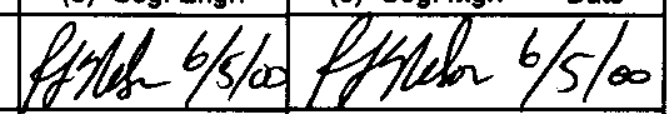

$\mathrm{RL} \mathrm{Nelson}$

$\mathrm{RL} \mathrm{Nelson}$ 


\title{
CH2M HILL Hanford Group, Inc.
}

\author{
Information \\ Resource Management Strategic Plan
}

\begin{abstract}
Executive Summary
This CH2M HILL Hanford Group, Inc. (CHG) Information Resource Management (IRM) Strategic Plan is the top-level planning document for applying information and information resource management to achieve the CHG mission for the management of the River Protection Project (RPP) waste tank farm.
\end{abstract}

The IRM organization, under the direction of the Chief Information Officer (CIO), is chartered to manage an IRM program that will implement the Information Resource Management Policy (RPP-POL-IRM, Rev 0, Effective December 22, 1999). This policy applies to work related to technical and business information including data, metadata, and related resources, such as personnel, funds, equipment, and technology, regardless of form or medium.

The key IRM strategy is for the CIO to direct information and information resource-related activities at a CHG level as a program, and for the IRM program to manage these information and information resource-related activities from the perspective of maintaining an information architecture. CHG IRM management includes involvement in the IRM plans and budgets for CHG business organizations.

An information architecture is a collection of information and information resource technologies arranged in a particular way to achieve a certain fit, form, and function. The CHG IRM information architecture consists of six major subarchitecture components-business, information, applications, data, technology, and work processes. This strategic plan describes the current situation, target, and proposal(s) to transition from the current situation to the target for each architectural component.

The current situation is where we are today in terms of services, support, and technology as they pertain to information and information-related requirements. The current situation throughout most of the CHG and RPP describes an ad hoc information architecture having a range of effectiveness from very good to poor. The shared telecommunications infrastructure CHG uses is very effective. Document and records management support is adequate. Information and data management, along with information system and work processes, offer opportunity for improvement. Most $\mathrm{CHG}$ organizations do not manage their information and information resources to U.S. Department of Energy (DOE) standards. On the other hand, the River Protection CHG Project's Process Engineering Group is managing their information and information resources according to the DOE standards and will be used as a best practices model.

The target identifies where we need to be or want to go in the areas of information and information-related services, support, and technology for each component of the information architecture. The plan's targets include documented information requirements; data and 


\section{RPP - 6212, Rev 1}

information management plans addressing information ownership, stewardship, and quality; information system consolidation and standardization; and streamlined policies and procedures.

The proposals are directed to obtaining the targets in a timely, efficient, and cost effective manner. This means that each proposal's goal is to successfully meet the challenge put forth by the targets for information, data and information management plans, information systems consolidations and standardization, and the streamlining of policies and procedures. The plan's proposals include, but are not limited to:

- Development of business models;

- Identification and documentation of key information;

- Development of a set of IRM principles, policies and procedures;

- Establishing Interface Control Documents between the CHG CIO and the Prime Hanford Management Contractor (PHMC) CIO Office for shared technical support;

- Adoption of a new data architecture including the establishment of a common data warehouse;

- Re-hosting the Job Control System (JCS) to a web-based platform;

- Identification and analysis of the existing records management and business systems to eventually create independent systems;

- Management of desktop hardware and software through a well-thought-out program; and,

- Integration of IRM planning and budgeting across CHG.

The CHG IRM Strategic Plan is an active, "living" document that will be the basis for present and future IRM strategies, direction, projects, and technology in support and delivery of information. 


\section{RPP - 6212, Rev 1}

\section{CONTENTS}

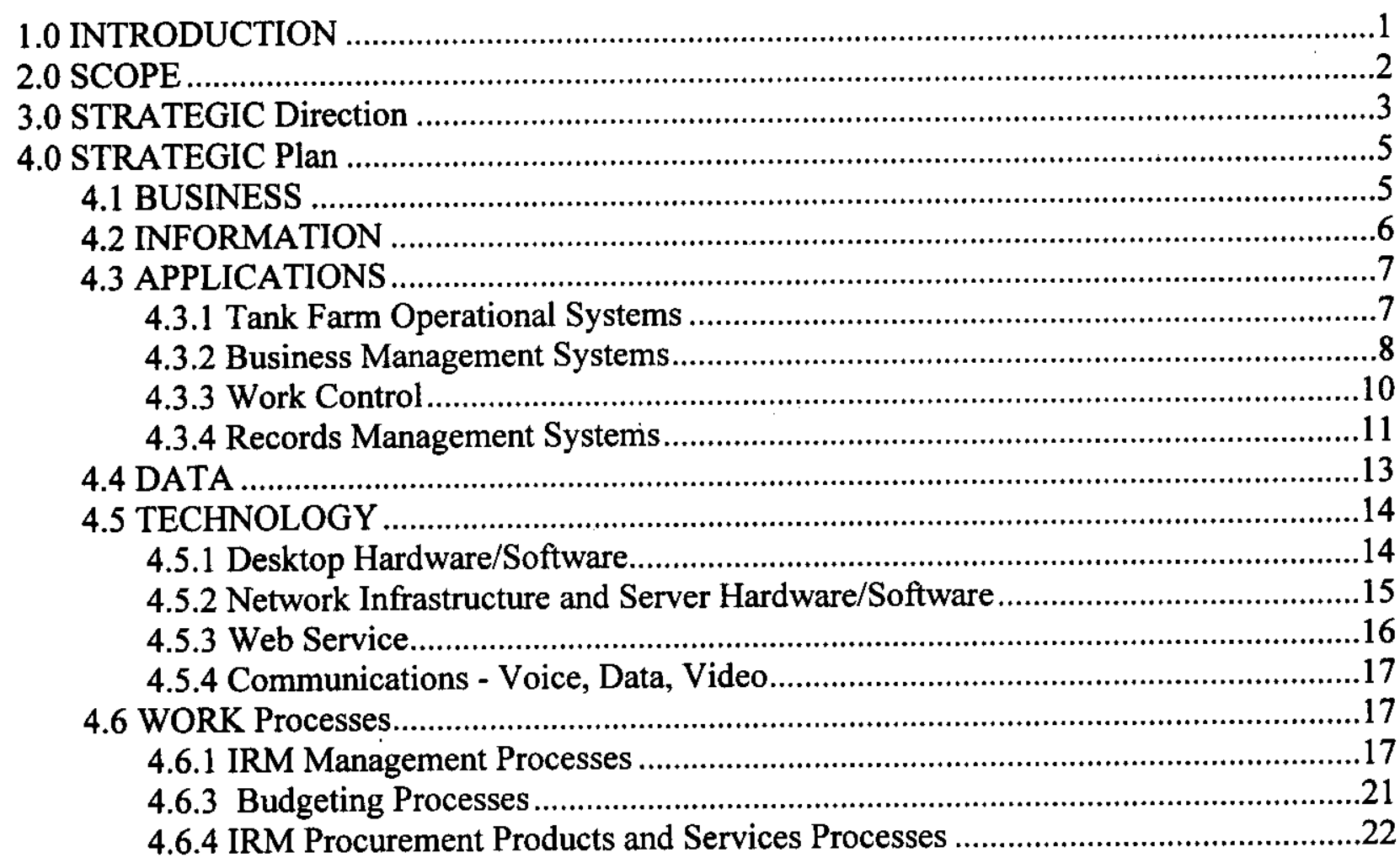

\section{FIGURE}

1. Information Architecture Model. 


\section{RPP - 6212, Rev 1}

\section{LIST OF TERMS}

Term

CHG

CIO

COTS

DOE

DOE-RL

ICD

IRM

ORP

PHMC

RPP

TFC
Description

CH2M HILL Hanford Group, Inc.

Chief Information Officer

Commercial Off The Shelf Software

U.S. Department of Energy

U.S. Department of Energy, Richland Operations Office

Interface Control Document

Information Resource Management

Office of River Protection

Project Hanford Management Contract

River Protection Project

Tank Farm Contractor 


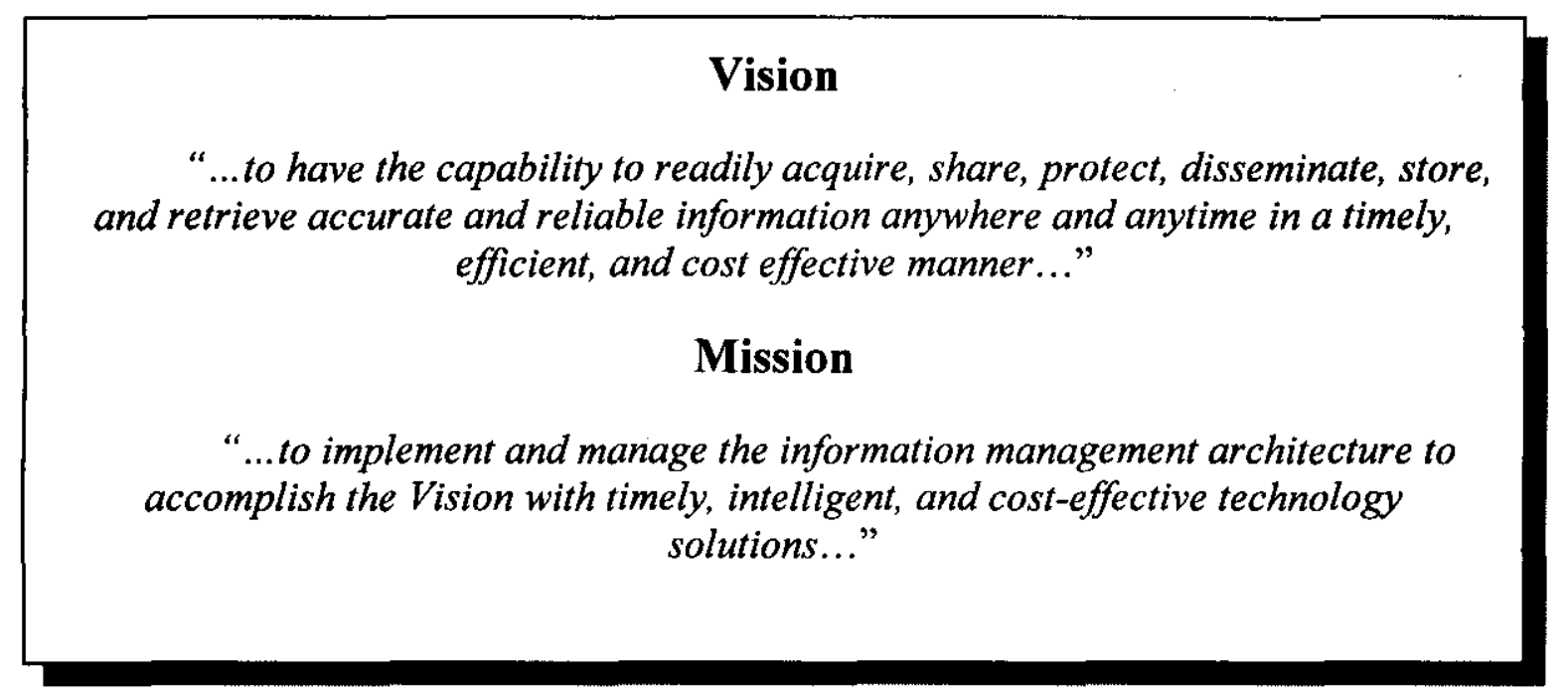

\subsection{INTRODUCTION}

Information is a key component to meeting strategic goals and a major driver to improving productivity. The CH2M HILL Hanford Group, Inc. (CHG) Information Resource Management (IRM) Strategic Plan is the top-level planning document for applying information and information resource management to achieve the CHG Mission. The CHG IRM organization, under the direction of the Chief Information Officer (CIO), is chartered to manage an IRM program. The CHG IRM program per the Information Resource Management Policy (RPPPOL-IRM, Rev. 0, December 22, 1999) is to ensure that information and information resourcerelated activities are planned, budgeted, and controlled in relation to achieving the CHG mission objectives, and are managed in accordance with the U.S. Department Of Energy (DOE) requirements. The major emphasis areas of the IRM program are data management and integration, information technology, information systems, media services, record management, and document control.

The CHG IRM program will implement and manage an information architecture. An information architecture is a collection of information and information resource technologies arranged in a particular way to achieve a certain fitness, form, and function. Effective information architecture provides the tools to support decision making and information sharing. Additionally, a well-designed and well-managed information architecture can provide the capability to readily acquire, share, protect, disseminate, store, and retrieve accurate and reliable information anywhere and anytime in a timely, efficient, and cost-effective manner. 


\section{RPP - 6212, Rev 1}

The IRM policy requires the CHG IRM program to accomplish the following:

- Establish Site standards for computing and networks

- Manage information based on business needs and objectives; capture data once, at their source of origin; and ensure data are accurate, traceable, and available to authorized users

- Develop simplified information architectures to support business processes at functional and company levels

- Promote the usefulness of information throughout its life cycle by using DOE-sanctioned resources and best-business practices

- Meet established standards for information that is collected, processed, stored, retrieved, viewed, and published by internal and external users

- Include records management functions in the design, development, operation, and termination of information systems

- Treat data as a site-wide resource, while preserving the confidentiality of sensitive data. Record, preserve, and make accessible to everyone, including the public, sufficient information to ensure the management and accountability of DOE programs and to protect the legal and financial rights of the federal government

- Provide a level of security commensurate with risk

- Improve the effectiveness of information technology dollars by using benchmarks and promoting the use of industry standards and commercial-off-the-shelf software

- Move to commercial-based service-level agreements for basic information resource management services.

\subsection{SCOPE}

This Strategic Plan is directed toward the CHG business units and, where appropriate, the U.S. Department of Energy Office of River Protection (ORP), DOE-Richland Operations Office, the Project Hanford Management Contract Team, Pacific Northwest National Laboratory, and the Waste Treatment Contractor.

This Strategic Plan articulates a strategic direction for IRM for $\mathrm{CHG}$, and where directed for ORP and the Program Office. This plan does not address the information resource management needs of the Waste Treatment Contractor. However it recognizes the need to provide effective technical and information interfaces with the Waste Treatment Contractor. The Strategic Plan addresses the current situation, identifies targets, and proposes specific activities to meet those targets. Working within the strategic framework created by this plan, some critical activities will be implemented immediately, while other activities will be phased in over the next several years. 


\section{RPP - 6212, Rev 1}

Appropriate reporting will be scheduled regularly through the existing program management review process.

The CHG IRM Strategic Plan is supplemented by other documents appropriate for achieving the CHG Mission. When the other documents are developed, they will include plans such as the IRM Execution Plan, the Annual Work Plan, budgets, tactical plans, and implementation plans.

This plan is designed as a "living document" and is placed under configuration management. As with most strategic plans, this plan will be revisited at least annually to assess the progress in implementing the plan and align the plan to reflect changes in the CHG's strategic directions and current IRM situation.

\subsection{STRATEGIC DIRECTION}

The CHG IRM CIO will act with respect to activities related to IRM. The CIO will establish the appropriate organizational structure, business processes, interface relationships, and staffing to operate an efficient and cost-effective IRM organization. The IRM Organization will ensure the existence of effective relationships and informational and technical interfaces and, where necessary, integration with the ORP, the Program Office, and, when required, related contractors.

The IRM architecture is the foundation on which the RPP acquires and uses information needed to successfully meet the $\mathrm{CHG}$ requirements. The information architecture enables information and information systems to be acquired or developed that meet a security level commensurate with the risk magnitude of the harm resulting from the loss, misuse, or unauthorized access to or modification of the information. In addition, this architecture facilitates configuration management, risk management, and data management disciplines for supported information requirements.

Conceptually, the information architecture is a framework that links programmatic mission and objectives to the business information and infrastructure. The CHG Information Architecture Model is patterned after the US Department of Energy Information Architecture Program Model, which in turn is an adaptation of the National Institute of Standards Technology Enterprise Architecture Model.

As shown in Figure 1, the Information Architecture Model contains the following five basic subarchitecture components and associated work processes. 


\section{RPP - 6212, Rev 1}

Figure 1. Information Architecture Model.

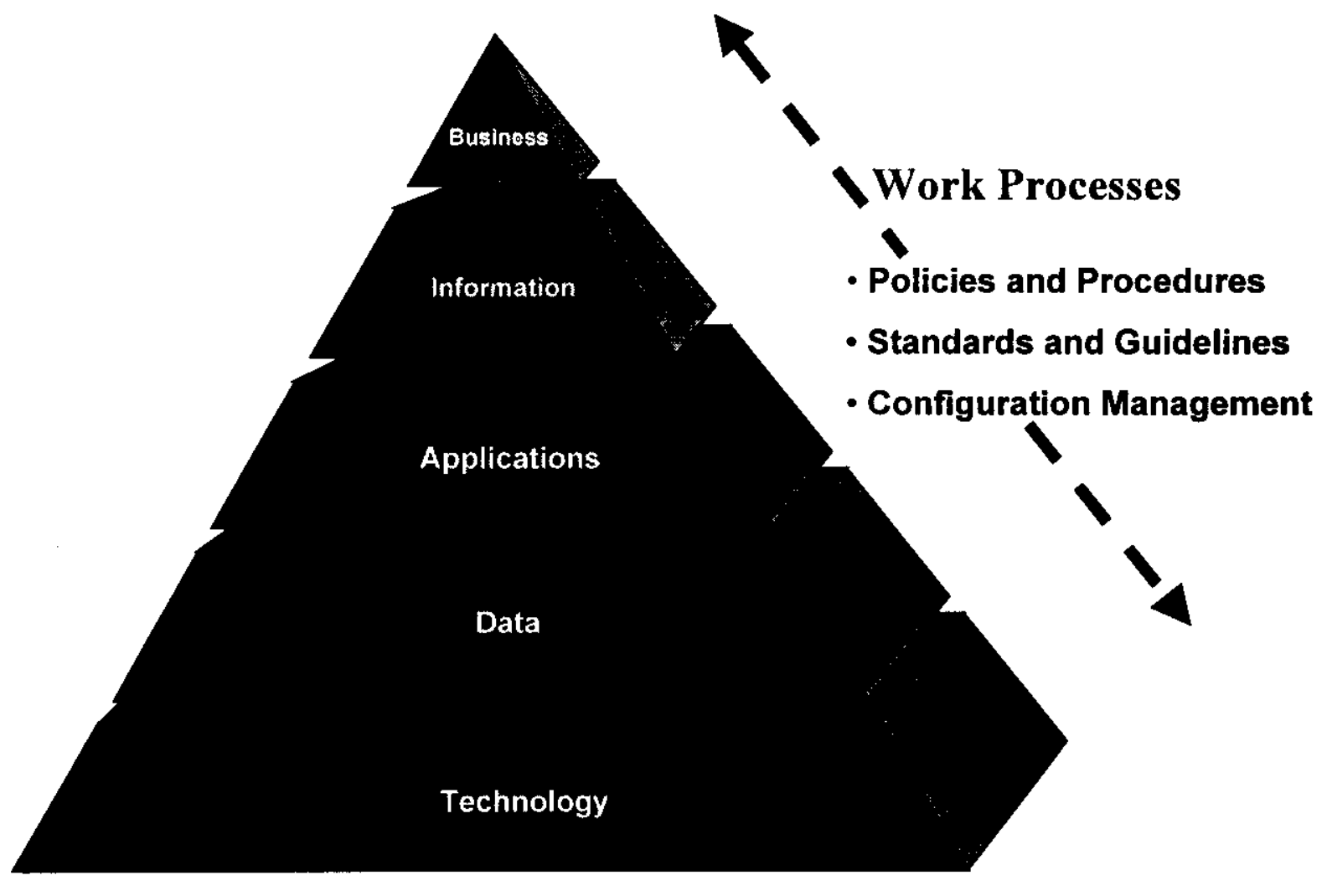

CHG0001-08 Rev 1

$1 / 27 / 00$

- Business: This component defines the core business procedures and processes of an enterprise at whatever level necessary to provide the requirements for infrastructure. The business entities within the individual business units are responsible for defining their procedures and processes to clearly identify their information requirements. IRM will provide guidance and, if necessary, assistance in developing these requirements.

- Information: This component identifies the subject matter, facts, figures, pictures, and relevant knowledge necessary to support the business procedures and processes. The information architecture also includes the procedures, standards, and systems that create and process all the above. IRM will provide guidance and, if necessary, assistance in identifying or developing these items.

- Applications: This component translates the requirements for information into sets of systems or applications that provide direct support to the business. IRM will work with the business function owners to design and implement a suite of systems that meet mission and program needs.

- Data: This component identifies the structure, definitions, and storage needs of the entities and elements and allows the processing of data into useable information. IRM 


\section{RPP - 6212, Rev 1}

will provide the standards and procedure that ensure data availability, reliability, and accessibility. Other organizations will provide data management plans.

- Technology: This component describes the physical layer of the infrastructure that is required to support the processing of data into useable information where and when it is needed. IRM will provide the technology to access and share information easily and seamlessly from any location. The technology component focuses on the computing, communications, and system software infrastructure necessary for accessing and sharing data and/or information efficiently and effectively. This component includes electronic mail service, remote network access, Internet and Intranet access, web site access, data warehousing, and telecommunications wide-area network connectivity.

- Work Processes: This component consists of the governing policies, directives, procedures, and standards that apply to information- and information resource-related activities. IRM will document and communicate these items throughout CHG to enable other organizations' participation and compliance. Technical and business experts from the other organizations will participate on boards and committees to assist IRM in defining and managing the information architecture.

\subsection{STRATEGIC PLAN}

The Strategic Plan describes the situation, target, and proposal from the view of each major Information Architecture component. The plan describes the current situation regarding an architectural component, the desired target "to be" condition, and the proposed activity to transition from the current situation to the target.

\subsection{BUSINESS}

Most organizations and processes do not operate from a business model that identifies their tasks and deliverables, participants, and the information they require and produce.

The following is the target and proposal for the information architecture business subarchitectural component.

\begin{tabular}{||l|l||}
\hline \multicolumn{1}{|c|}{ Target } & \multicolumn{1}{|c||}{ Proposal } \\
\hline $\begin{array}{l}\text { Key organizations and processes have } \\
\text { documented business models depicting } \\
\text { their major tasks, deliverables, participants, } \\
\text { and the information they require and } \\
\text { produce. }\end{array}$ & $\begin{array}{l}\text { The CHG IRM program requires the major } \\
\text { organizations and processes to develop and } \\
\text { publish business models depicting their } \\
\text { major tasks, deliverables, and participants, } \\
\text { and the information they require and } \\
\text { produce. }\end{array}$ \\
\hline
\end{tabular}




\subsection{INFORMATION}

Currently, data reside in many locations and often the same data are found in several systems. Information is not managed using a centralized process and the ability to retrieve data often depends on the knowledge of individuals rather than processes. Data often are accessed through standalone databases and as many as 100 electronic information systems, rather than through uniform information management systems. CHG depends on several information systems managed by the Project Hanford Management Contract (PHMC) and Department of Energy, Richland Operations Office (DOE-RL). These systems provide management, personnel, operational documents, records, and performance information.

The following targets and proposals are for the information architecture information subarchitectural component.

\begin{tabular}{||l|l||}
\hline \multicolumn{1}{|c|}{ Target } & \multicolumn{1}{|c||}{ Proposal } \\
\hline $\begin{array}{l}\text { Relevant information needed for } \\
\text { organizations and processes is identified } \\
\text { and documented. }\end{array}$ & $\begin{array}{l}\text { Use the business models of the major } \\
\text { organizations and business processes to } \\
\text { identify and document the relevant } \\
\text { information. }\end{array}$ \\
\hline $\begin{array}{l}\text { The workforce and regulators have access } \\
\text { to an inventory of available information. } \\
\text { An electronic directory lists the } \\
\text { information and provides details on } \\
\text { location, owner or steward, pedigree, and } \\
\text { how and in what format the data can be } \\
\text { obtained. }\end{array}$ & $\begin{array}{l}\text { Develop an electronic information } \\
\text { directory that lists data and information and } \\
\text { describes their location, access, owner or } \\
\text { steward, format, and quality. }\end{array}$ \\
\hline $\begin{array}{l}\text { Information and data are managed through } \\
\text { a formal process that identifies the owner, } \\
\text { trustee, custodian, steward, users, and } \\
\text { pedigree. Policies, procedures, and } \\
\text { guidance are available to develop and } \\
\text { manage the process. This target will also } \\
\text { enhance the data sub-architecture } \\
\text { component. }\end{array}$ & $\begin{array}{l}\text { Develop a set of policies, procedures, and } \\
\text { guidelines on information and data } \\
\text { management principles. These principles } \\
\text { should define and address how to establish } \\
\text { ownership, trusteeship, custodianship, } \\
\text { stewardship, and quality of information. }\end{array}$ \\
\hline
\end{tabular}




\section{RPP - 6212, Rev 1}

\subsection{APPLICATIONS}

The information management application systems include tank farm operations, business management, work control, and records management. These applications will cut across programs and staff organizations.

\subsubsection{Tank Farm Operational Systems}

The IRM information architecture will standardize systems used in tank farm operations to manage information to monitor and control tank waste; receive and store treated waste; and deliver waste to the vitrification Waste Treatment Contractor. The various systems used for database repositories and business management functions also will be updated and standardized.

Many systems were developed in house; others were developed and/or maintained by outside contractors. Multiple contractors share systems, but certain organizations and companies may have proprietary ownership, where the information is treated as a company asset and is not readily available to others.

Data reside in many locations and are used by many systems. This redundancy in applications and data creates inconsistencies. Several systems do not share required data through information exchange or integration and do not have standardized interfaces.

The majority of the systems have adequate configuration control for life-cycle activities.

Many systems reside on different platforms, which in turn require additional IRM resources. Several systems were developed in what is now known as older technology. Constraints such as budget limitations and new release volumes prevent some systems from being kept current.

Lack of automation capabilities in some functional areas of the Tank Farm Contractor Engineering departments result in inefficient completion of assignments, leading to increased costs. In some cases these inefficiencies may result in increased labor costs of as much as 70 to 80 percent.

The following targets and proposals are for the information architecture application tank farm operation systems sub-architectural component. 


\begin{tabular}{|l|l|}
\hline \multicolumn{1}{|c|}{ Target } & \multicolumn{1}{|c|}{ Proposal } \\
\hline No redundant systems. & $\begin{array}{l}\text { Identify a suite of Tank Farm Operation } \\
\text { information systems that will provide the } \\
\text { necessary business and technical functions } \\
\text { without duplication. Modify or retire } \\
\text { duplicate systems. }\end{array}$ \\
\hline $\begin{array}{l}\text { Information systems share data through } \\
\text { information exchange. }\end{array}$ & $\begin{array}{l}\text { Implement and try to adhere to a design } \\
\text { objective to store data in only one place } \\
\text { and provide capability for key data to be } \\
\text { accessed by multiple systems. }\end{array}$ \\
\hline $\begin{array}{l}\text { Engineering drawings are widely available } \\
\text { and under configuration control. }\end{array}$ & $\begin{array}{l}\text { Publish engineering drawings on the web } \\
\text { and capture redlining. }\end{array}$ \\
\hline Standardize interfaces. & $\begin{array}{l}\text { Establish a common data warehouse that } \\
\text { applications feed and update. }\end{array}$ \\
\hline $\begin{array}{l}\text { Applications are de-coupled from the } \\
\text { PHMC. }\end{array}$ & $\begin{array}{l}\text { Identify those systems that can be and } \\
\text { show a benefit if separated from the } \\
\text { PHMC. }\end{array}$ \\
\hline $\begin{array}{l}\text { Labor-intensive activities for which } \\
\text { automated solutions are available are } \\
\text { replaced, thereby freeing up personnel for } \\
\text { other work. }\end{array}$ & $\begin{array}{l}\text { Define, analyze, and select most efficient } \\
\text { and cost-effective automated method to } \\
\text { reduce labor-intensive engineering } \\
\text { functions. Use Commercial-Off-The-Shelf } \\
\text { (COTS) software whenever possible. }\end{array}$ \\
\hline
\end{tabular}

\subsubsection{Business Management Systems}

Currently CHG shares the DOE-RL PHMC business systems. The extent of the shared environment limits the ability for CHG to provide the means to keep current and expand or modify the systems to meet their specific needs. In addition, the current configuration of the Business Management System allows non-CHG organizations to have access to and administrative oversight for CHG-specific data and information.

The PHMC Business Management System is an integrated set of COTS. The Business Management System, as implemented, only supports one company with the major subcontractors supported as "departments." The Hanford Site structure now consists of a DOE-RL prime 


\section{RPP - 6212, Rev 1}

contractor and an ORP prime contractor. The system could be modified to provide better company-level separation, but modification is very expensive, in both development and maintenance and the resulting system still would not provide $\mathrm{CHG}$ full autonomy. Vendor consultants, who traditionally are more expensive, supply the commercial-off-the-shelf core competency for new module implementations and major version upgrades. The Business Management System has a complex interface infrastructure. Some systems required to support CHG do not interface with the Business Management System, while other systems not needed to support CHG do interface with the Business Management System. The Business Management System resides on multiple server platforms, which results in redundant operations and maintenance personnel.

The shared business systems infrastructure complicates configuration control. This multiple shared environment is administered and functionally managed by a single organization, the DOE-RL PHMC CIO. CHG recognizes that by staying with the shared systems, they are exposed to consequences of future DOE-RL and PHMC contract changes and funding levels, and they are tied long term to the PHMC for future business automation. In addition, the business systems are receiving direction from different DOE organizations.

As a DOE entity, the ORP uses the DOE-approved business systems for DOE Headquarters business.

The following targets and proposals are for the information architecture application Business Management System sub-architectural component.

\begin{tabular}{|l|l|}
\hline \multicolumn{1}{|c|}{ Target } & \multicolumn{1}{|c|}{ Proposal } \\
\hline $\begin{array}{l}\text { CHG human resources, project } \\
\text { management and technical data are under } \\
\text { full control of CHG. }\end{array}$ & $\begin{array}{l}\text { Perform a "fit/gap" analysis on the current } \\
\text { business systems to determine if they meet } \\
\text { CHG specific business requirements. } \\
\text { Provide an alternative analysis for CHG } \\
\text { business systems options using COTS } \\
\text { software whenever possible. } \\
\text { Gain approval, sponsorship, and funding } \\
\text { for the Transition Plan project. } \\
\text { Select the most efficient, cost-effective } \\
\text { alternative and develop a transition plan for } \\
\text { the business systems. } \\
\text { Perform the transition plan as a high- } \\
\text { priority project. }\end{array}$ \\
\hline
\end{tabular}




\section{RPP - 6212, Rev 1}

\begin{tabular}{||l|l||}
\hline \multicolumn{1}{|c|}{ Target } & \multicolumn{1}{|c|}{ Proposal } \\
\hline $\begin{array}{l}\text { Technical resources are available for } \\
\text { transition and support of CHG business } \\
\text { systems. }\end{array}$ & $\begin{array}{l}\text { Develop an approved Interface Control } \\
\text { Document (ICD) between the CHG CIO } \\
\text { and PHMC CIO for shared technical } \\
\text { resource support. }\end{array}$ \\
\hline $\begin{array}{l}\text { CHG continues to participate in shared } \\
\text { systems and infrastructure that support Site } \\
\text { information (i.e., desktop software, } \\
\text { network infrastructure). }\end{array}$ & $\begin{array}{l}\text { Develop an approved ICD with the PHMC- } \\
\text { CIO to ensure CHG participation and the } \\
\text { planning and use of shared systems and } \\
\text { infrastructure. }\end{array}$ \\
\hline
\end{tabular}

\subsubsection{Work Control}

CHG management determined that the existing work control processes do not adequately support its contractual and regulatory obligations. In fiscal year 1998, Lockheed Martin Hanford Corporation (LMHC) management made a business case to implement the INDUS ${ }^{1}$ Work Management Suite. A fit/gap analysis was conducted in fiscal year 1999 that provides a conceptual view of how a complete, integrated information system could work given the interface databases and current business processes. In fiscal year 1999, the Work Management Master Equipment List was implemented. Currently, the PHMC owns and controls the software licenses for PeopleSoft and INDUS PassPort. This greatly affects CHG implementation plans because the individual plans may not be synchronized with the business needs of the PHMC.

A 3-year plan for implementing the Work Management Suite was developed in fiscal year 1999. As of February 17, 2000, an executive assessment, by CHG, concluded that the INDUS Work Management Suite was not a cost effective solution that would bring the expected return on investment or deliver the needs of the corporation under CHG's prime contract. With modifications, the current Job Control System will be extended for two years.

The following targets and proposals are for the information architecture application Work Control sub-architecture component.

\begin{tabular}{|l|l|}
\hline \multicolumn{1}{|c|}{ Target } & \multicolumn{1}{c|}{ Proposal } \\
\hline $\begin{array}{l}\text { An ICD between the PHMC CHG for using } \\
\text { the Job Control System. }\end{array}$ & $\begin{array}{l}\text { IRM CIO will interface with PHMC CIO to } \\
\text { establish a cooperative ICD for continued } \\
\text { use of the Job Control System. }\end{array}$ \\
\hline
\end{tabular}

' INDUS is a trademark of The Indus Group, Inc. 


\section{RPP - 6212, Rev 1}

\begin{tabular}{|l|l|}
\hline \multicolumn{1}{|c|}{ Target } & \multicolumn{1}{|c|}{ Proposal } \\
\hline $\begin{array}{l}\text { The Job Control System will retain its } \\
\text { current functionality and will be modified } \\
\text { to meet the short-term needs of work } \\
\text { control. Anticipated full implementation } \\
\text { by September 30, 2001. }\end{array}$ & $\begin{array}{l}\text { Re-host or upgrade the Job Control System } \\
\text { to a web-based platform. } \\
\text { Report Writer tool will be the site standard } \\
\text { Crystal Reports. } \\
\text { Investigate the use of Primavera, the site } \\
\text { standard to be launched from the Job } \\
\text { Control System in a simple format for } \\
\text { planners/engineers to insert initial } \\
\text { information, such as resources, duration, } \\
\text { and linkages. }\end{array}$ \\
\hline $\begin{array}{l}\text { Establish work control to be under full } \\
\text { control of CHG. }\end{array}$ & $\begin{array}{l}\text { Provide an alternative analysis for CHG } \\
\text { work control system options. } \\
\text { Gain approval, sponsorship, and funding } \\
\text { for the Transition Plan project. } \\
\text { Select the most efficient, cost-effective } \\
\text { alternative and develop a transition plan for } \\
\text { the business systems. } \\
\text { Perform the transition plan as a high- } \\
\text { priority project. }\end{array}$ \\
\hline $\begin{array}{l}\text { Technical resources will be available for } \\
\text { transition and support of the CHG business } \\
\text { systems. }\end{array}$ & $\begin{array}{l}\text { Develop an approved ICD between the } \\
\text { CHG CIO and PHMC ClO for shared } \\
\text { technical resource support. }\end{array}$ \\
\hline network infrastructure). & $\begin{array}{l}\text { Develop an approved ICD with the PHMC- } \\
\text { CIO to ensure CHG participation and the } \\
\text { planning and use of shared systems and } \\
\text { infrastructure. }\end{array}$ \\
\hline
\end{tabular}

\subsubsection{Records Management Systems}

Multiple laws, regulations, and notices impose many requirements on a document control and records management program. Records management and document control requirements are well defined and, for the most part, are used by contractors, with slightly varying interpretations. Currently, the primary source of record data is hard copy, although some electronic files are being determined to be record data. In many cases the hard copy is scanned and made available electronically, which allows for adequate retrieval of electronic files; however, the hard copy 


\section{RPP - 6212, Rev 1}

must still be retained as the record. Although individual companies and organizations manage numerous records using various documentation management systems, for the most part CHG will share the PHMC systems. The extent of the shared environment limits the CHG's ability to provide the means to keep current with evolving technology, and to expand or modify the systems to meet their specific needs.

The following targets and proposals are for the information architecture application subarchitectural document control and records management systems component.

\begin{tabular}{|c|c|}
\hline Target & Proposal \\
\hline $\begin{array}{l}\text { Short Term } \\
\text { (1)) Implement Independent systems for } \\
\text { CHG and Records and Documentation } \\
\text { information sets, to be- managed } \\
\text { independently of the PHMC. } \\
\text { (2) Continued participation in shared "Site" } \\
\text { systems where required by all or some } \\
\text { contractors. These include such systems as } \\
\text { the engineering drawing system that } \\
\text { supports creation of drawings, the database } \\
\text { that allows for retrieval of boxes of records, } \\
\text { and the records inventory for CHG. } \\
\text { Specifically, these are the Engineering } \\
\text { Drawing Management System, the Records } \\
\text { Holding Area - Management Information } \\
\text { System, and the Records Inventory and } \\
\text { Disposition Schedule databases. }\end{array}$ & $\begin{array}{l}\text { (1) Investigate "cloning" the currently } \\
\text { shared systems to provide immediate CHG } \\
\text { autonomy. } \\
\text { (2) Identify Site shared systems that are } \\
\text { used by multiple contractors, and develop } \\
\text { an ICD to ensure that work processes are } \\
\text { established to manage the interfaces } \\
\text { required for managing the shared systems. } \\
\text { Create independent systems for retrieval } \\
\text { and configuration control databases that are } \\
\text { not subject to an ICD. }\end{array}$ \\
\hline $\begin{array}{l}\text { Long Term } \\
\text { Improved document control and records } \\
\text { management systems that provide easy } \\
\text { access to information (documents and } \\
\text { records) in a standardized electronic format } \\
\text { (images and electronic files), standardized } \\
\text { user interfaces, and identification of } \\
\text { selected electronic records as record } \\
\text { materials. }\end{array}$ & $\begin{array}{l}\text { Form a project team to define and analyze } \\
\text { the existing records and documentation } \\
\text { requirements, interpret those requirements, } \\
\text { evaluate existing databases and systems, } \\
\text { perform an alternative analysis, and } \\
\text { propose a path forward using COTS } \\
\text { software whenever possible. }\end{array}$ \\
\hline
\end{tabular}




\section{RPP - 6212, Rev 1}

\subsection{DATA}

The repository for some data required by $\mathrm{CHG}$ resides with the PHMC (i.e., financial, human resources, and work management). Additionally, other data required by $\mathrm{CHG}$ are owned and reside wholly in ORP systems.

Regardless of the location of these data, $\mathrm{CHG}$ needs a standard set of guiding principles to effectively manage their data. The guiding principles for the PHMC currently are aligned with the guiding principles for $\mathrm{CHG}$. CHG acknowledges that sharing of common data (data common to the PHMC and CHG is essential and that the infrastructure for providing common data to applications is a part of the basic data architecture. However, the following issues highlight the need for CHG to develop its own set of guiding principles.

- Access to data and security measures on data are not controlled with enough consistency throughout the two programs.

- Data structures, naming standards and guidelines, and compatible storage schema are not incorporated to the extent necessary to allow efficient data sharing among systems and among users.

- Most CHG data are not traceable from their point of origin to their destination. This lack of information on data makes it hard to assure their quality and veracity.

The following targets and proposals are for the information architecture data sub-architectural component.

\begin{tabular}{|c|c|}
\hline Target & Proposal \\
\hline $\begin{array}{l}\text { An IRM Data Administration Council } \\
\text { reviews, approves, and establishes CHG- } \\
\text { wide data naming standards and guidelines. } \\
\text { The Council will own and maintain the } \\
\text { CHG data dictionary. }\end{array}$ & $\begin{array}{l}\text { Establish a Data Administration Council } \\
\text { that reviews, approves, and establishes } \\
\text { CHG-wide data naming standards and } \\
\text { guidelines. The Council also will own and } \\
\text { maintain CHG data dictionary. }\end{array}$ \\
\hline $\begin{array}{l}\text { A sufficient degree of autonomy and } \\
\text { commonality exists regarding the data } \\
\text { needs of } \mathrm{CHG} \text { and the PHMC. }\end{array}$ & $\begin{array}{l}\text { The CHG IRM CIO will interface with } \\
\text { PHMC CIO to establish commonality and } \\
\text { identify autonomy. }\end{array}$ \\
\hline $\begin{array}{l}\text { Existing data architecture and infrastructure } \\
\text { allow CHG and PHMC to deviate where } \\
\text { necessary and prudent, while still using } \\
\text { common data and infrastructure. }\end{array}$ & $\begin{array}{l}\text { Adopt or develop a data architecture that } \\
\text { provides for the following: } \\
\text { Integration into the Hanford Site } \\
\text { technical infrastructure; } \\
\text { - Support for data warehousing and } \\
\text { operational data stores }\end{array}$ \\
\hline
\end{tabular}




\section{RPP - 6212, Rev 1}

\begin{tabular}{|c|c|}
\hline Target & Proposal \\
\hline & $\begin{array}{l}\text { Fault tolerance such that failure of a } \\
\text { single system does not negatively } \\
\text { impact other systems; and, } \\
\text { - Security such that data can be } \\
\text { compartmentalized for access on a } \\
\text { need-to-know basis. }\end{array}$ \\
\hline $\begin{array}{l}\text { Abstraction layers exist between data } \\
\text { providers and users so deviation between } \\
\text { CHG and PHMC application and data will } \\
\text { have minimal negative impact. }\end{array}$ & $\begin{array}{l}\text { Adopt or develop a data architecture that } \\
\text { provides for abstraction between the } \\
\text { application generating the data and the } \\
\text { application using the data. }\end{array}$ \\
\hline $\begin{array}{l}\text { CHG and the PHMC coordinate changes of } \\
\text { data naming standards and guidelines. }\end{array}$ & $\begin{array}{l}\text { Adopt or develop data naming standards } \\
\text { and guidelines. }\end{array}$ \\
\hline $\begin{array}{l}\text { CHG-specific data are "owned" by named } \\
\text { individuals (data administrator) within } \\
\text { CHG. }\end{array}$ & $\begin{array}{l}\text { Adopt or develop clear and concise guiding } \\
\text { principles for data management. }\end{array}$ \\
\hline $\begin{array}{l}\text { Data shared between CHG and the PHMC } \\
\text { have CHG and PHMC owners, who will be } \\
\text { responsible for their organization's portion } \\
\text { of the data. For shared data, decisions are } \\
\text { made jointly. }\end{array}$ & $\begin{array}{l}\text { Adopt or develop a data architecture that } \\
\text { provides for tracing data from their point of } \\
\text { origin to their ultimate destination. }\end{array}$ \\
\hline $\begin{array}{l}\text { A Hanford Site data dictionary identifies } \\
\text { those data that are PHMC specific, } \mathrm{CHG} \\
\text { specific, or common to both. }\end{array}$ & $\begin{array}{l}\text { Adopt or develop data dictionaries to } \\
\text { provide necessary and sufficient } \\
\text { information on data. }\end{array}$ \\
\hline
\end{tabular}

"Adopt or develop" indicates CHG will review the PHMC legacy system in light of the CHG mission.

\subsection{TECHNOLOGY}

\subsubsection{Desktop Hardware/Software}

The PHMC's Technology Engineering organization adequately identifies the latest technology and applications for present and future use. Not all desktop hardware and software meet the industry-recommended standard refresh rate of every 3 to 4 years.

The following targets and proposals are for the information architecture technology desktop hardware/software sub-architectural component. 


\begin{tabular}{|c|c|}
\hline Target & Proposal \\
\hline $\begin{array}{l}\text { Desktop hardware used by } \mathrm{CHG} \text {, } \\
\text { regardless of ownership, meets a CHG- } \\
\text { defined refresh rate to provide a standard } \\
\text { application desktop platform and } \\
\text { interoperability. } \\
\text { Annual refresh rate is } 25 \% \text { of the desktop } \\
\text { hardware inventory. }\end{array}$ & $\begin{array}{l}\text { Define standards for managed hardware } \\
\text { and software for CHG. } \\
\text { Submit and obtain budget approval each } \\
\text { year to replace a minimum of } 25 \% \text { of the } \\
\text { desktop hardware inventory. }\end{array}$ \\
\hline $\begin{array}{l}\text { Regular reviews of present and future } \\
\text { needs of CHG and identification of the } \\
\text { latest technology and applications to meet } \\
\text { those requirements continue to be } \\
\text { conducted regularly. }\end{array}$ & $\begin{array}{l}\text { Determine if CHG will continue to use the } \\
\text { PHMC desktop hardware, software, and } \\
\text { licenses. } \\
\text { Develop and implement a desktop- } \\
\text { managed hardware and software program } \\
\text { for CHG. } \\
\text { Continue to use the services of a research } \\
\text { and development organization to provide } \\
\text { the latest technology and applications } \\
\text { information to CHG. }\end{array}$ \\
\hline $\begin{array}{l}\text { Continue to use current Site standards for } \\
\text { Office Automation System. }\end{array}$ & $\begin{array}{l}\text { Implement the current site standard, } \\
\text { Microsoft Office, for desktop hardware. }\end{array}$ \\
\hline
\end{tabular}

\subsubsection{Network Infrastructure and Server Hardware/Software}

The PHMC network capacity is adequate for most current applications under normal use. The PHMC installed a new network backbone, but certain Site facilities cannot connect because old technology is being used in some areas. CHG shares some of the PHMC-controlled network servers, which are PHMC Site standard compliant and are under configuration management. Some CHG-owned network servers are not managed to PHMC Site standards.

The following targets and proposals are for the information architecture technology network infrastructure and server hardware/software sub-architectural component. 


\section{RPP - 6212, Rev 1}

\begin{tabular}{|l|l|}
\hline \multicolumn{1}{|c|}{ Target } & \multicolumn{1}{|c|}{ Proposal } \\
\hline $\begin{array}{l}\text { CHG continues to use the PHMC network } \\
\text { infrastructure services. }\end{array}$ & $\begin{array}{l}\text { Develop and implement a managed } \\
\text { hardware/software program for network } \\
\text { servers. } \\
\text { The CHG IRM CIO interfaces with the } \\
\text { PHMC CIO to participate in and concur } \\
\text { with any major changes to or replacement } \\
\text { of current network infrastructure services. }\end{array}$ \\
\hline $\begin{array}{l}\text { CHG has reliable, consistent network } \\
\text { infrastructure and file services. }\end{array}$ & $\begin{array}{l}\text { Establish a CHG Service Level Agreement } \\
\text { with the PHMC. }\end{array}$ \\
\hline $\begin{array}{l}\text { Security standards for network operations } \\
\text { are in use to ensure compatibility with the } \\
\text { CHG mission. }\end{array}$ & $\begin{array}{l}\text { Establish security policy for network } \\
\text { communications and services. }\end{array}$ \\
\hline
\end{tabular}

\subsubsection{Web Service}

The PHMC has defined the technical policies, procedures, operations, support tools, and technology infrastructure for the Intranet and Internet web site use. However, CHG has requirements to access other information or Web services that are not currently available within the shared infrastructure. Web development does not have a consistent approach to quality and technology infusion. As a result, there are numerous fragmented, non-integrated, sometimes duplicate sources of information.

The following targets and proposals are for the information architecture technology web service sub-architectural component.

\begin{tabular}{||l|l||}
\hline \multicolumn{1}{|c|}{ Target } & \multicolumn{1}{|c||}{ Proposal } \\
\hline $\begin{array}{l}\text { A standard set of World Wide Web } \\
\text { services is available to support the CHG } \\
\text { requirements. Enhanced services may } \\
\text { include computer-based training, command } \\
\text { information, standard service orders, } \\
\text { procurement, policies, and procedures. }\end{array}$ & $\begin{array}{l}\text { Analyze existing web services and } \\
\text { information against CHG requirements. }\end{array}$ \\
$\begin{array}{l}\text { Develop and implement CHG web } \\
\text { requirements. }\end{array}$ \\
$\begin{array}{l}\text { Establish web standard application } \\
\text { platform. }\end{array}$ \\
\hline $\begin{array}{l}\text { Standards for web servers, management } \\
\text { infrastructure, development tools, data }\end{array}$ & $\begin{array}{l}\text { Develop and publish standards for web } \\
\text { design, development, and implementation }\end{array}$ \\
\hline
\end{tabular}




\section{RPP - 6212, Rev 1}

\begin{tabular}{||l|l||}
\hline \multicolumn{1}{|c|}{ Target } & \multicolumn{1}{|c|}{ Proposal } \\
\hline access tools, and browsers are in use. & $\begin{array}{l}|c| \\
\text { including standards for maintenance and } \\
\text { operations. }\end{array}$ \\
& $\begin{array}{l}\text { Define web service providers and develop } \\
\text { associate service level agreements. } \\
\text { Participate in and concur with any major } \\
\text { changes to or replacement of current web } \\
\text { services. }\end{array}$ \\
\hline
\end{tabular}

\subsubsection{Communications - Voice, Data, Video}

CHG is currently using the PHMC services for voice, data, and video communications.

The following targets and proposals are for the information architecture technology communications - voice, data, and video sub-architectural component.

\begin{tabular}{|l|l|}
\hline \multicolumn{1}{|c|}{ Target } & \multicolumn{1}{|c|}{ Proposal } \\
\hline $\begin{array}{l}\text { CHG has reliable and consistent voice, } \\
\text { data, and video services. }\end{array}$ & $\begin{array}{l}\text { Establish CHG service level agreements } \\
\text { with the PHMC. }\end{array}$ \\
\hline $\begin{array}{l}\text { CHG continues to use the PHMC } \\
\text { communication services and infrastructure. }\end{array}$ & $\begin{array}{l}\text { Establish a process to ensure the IRM CIO } \\
\text { interfaces with the PHMC CIO to } \\
\text { participate in and concur with any major } \\
\text { changes to or replacement of current voice, } \\
\text { data, and video services. }\end{array}$ \\
\hline
\end{tabular}

\subsection{WORK PROCESSES}

\subsubsection{IRM Management Processes}

CHG organizations and business process managers are responsible for completing work that often requires information or information resource-related activities. These managers primarily focus on completing the task at hand with less concern for adhering to the standard information architecture. Furthermore, most are not aware of or are indifferent to the existing IRM policies, procedures, standards, or guidelines. Most do not know the proper channels for acquiring information services or products. CHG's Process Engineering Group is an exception to this situation. The Process Engineering Group runs a well managed, information management 


\section{RPP - 6212, Rev 1}

process and its information management technologies have saved hundreds of thousands of dollars. However, the organization has not been successful in leveraging its best practices for use in other organizations.

CHG organizations are not uniformly applying accepted engineering practices and a disciplined approach in developing and implementing information and information resources.

Telecommunication, data, records, and web pages are a few examples where designs are not consistent and may not even interface properly with the PHMC-controlled systems or other outside entities.

Today each project is responsible for its own configuration control; in some cases it is not being done at all. The ORP Program Office has identified a need to provide an integrated configuration management process that is flexible and responsive to project managers and implementers. At the same time, the Program Office must ensure that Program Office IRM projects have a controlled cost, schedule, and scope baseline and that changes to the baseline are logical and disciplined.

Information and information resource-related activities are not on a scheduled, CHG-level, review cycle. Customer expectations, issue resolution, and adherence to an information architecture can affect the entire CHG.

Currently no central "clearing house" is established for naming convention standards. Many items, such as tanks, have several aliases. This presents a problem when trying to locate information.

To begin operations on October 1, 1999, LMHC, the TFC at that time, adopted the current IRM Project Hanford practices, policies, standards, guidelines, and procedures. As currently formulated, some of these may not apply to CHG, who became the TFC in December 1999.

The ORP Program Office staff members are employees of the ORP, with support from the TFC, Pacific Northwest National Laboratory, and the Waste Treatment Contractor. Some staff members are located in ORP facilities; others remain at their home offices. Many staff members are part-time ORP and TFC contributors. Staff members have different corporate cultures, use different information technologies and security mechanisms, and are knowledgeable about subsets of the corporate data. This diversity adds to the capabilities of the Program Office, but also introduces communication problems, security issues, and inefficiencies.

The following targets and proposals are for the IRM information architecture work process management component:

\begin{tabular}{|l|l|}
\hline \multicolumn{1}{|c|}{ Target } & \multicolumn{1}{|c|}{ Proposal } \\
\hline $\begin{array}{l}\text { Each major CHG organization or business } \\
\text { process has an individual assigned as the } \\
\text { single point of authority and responsibility, }\end{array}$ & $\begin{array}{l}\text { Each major CHG organization will appoint } \\
\text { an individual as the single point of } \\
\text { authority and responsibility, representing }\end{array}$ \\
\hline
\end{tabular}




\section{RPP - 6212, Rev 1}

\begin{tabular}{|c|c|}
\hline Target & Proposal \\
\hline $\begin{array}{l}\text { representing the delegating organization on } \\
\text { information and information resource- } \\
\text { related directions, services, support, and } \\
\text { issues. This individual also is assigned as } \\
\text { an integral member of the CIO's IRM } \\
\text { organization. }\end{array}$ & $\begin{array}{l}\text { the delegating organization on information- } \\
\text { and information resource-related directions, } \\
\text { services, support, and issues. This } \\
\text { individual is assigned as an integral } \\
\text { member of the CIO's IRM organization. }\end{array}$ \\
\hline $\begin{array}{l}\text { IRM best practices are extended CHG-wide } \\
\text { from the originating organization. }\end{array}$ & $\begin{array}{l}\text { Find and extend best IRM practices CHG- } \\
\text { wide. Candidates include CHG's Process } \\
\text { Engineering group and the engineering } \\
\text { group that manages the tank SY-101 } \\
\text { DACS. }\end{array}$ \\
\hline $\begin{array}{l}\text { Individuals assigned as a CHG } \\
\text { organization's single point of authority for } \\
\text { information- and information resource- } \\
\text { related activities will understand the } \\
\text { guidelines, policies, standards, and } \\
\text { procedures for managing information and } \\
\text { information resource-related activities } \\
\text { including procuring IRM products and } \\
\text { services. }\end{array}$ & $\begin{array}{l}\text { Train individuals assigned as a CHG } \\
\text { organization's single point of authority for } \\
\text { information- and information resource- } \\
\text { related activities on IRM guidelines, } \\
\text { policies, standards, and procedures. }\end{array}$ \\
\hline $\begin{array}{l}\text { An IRM Advisory Committee made up of } \\
\text { representatives from key ORP } \\
\text { organizations and the major IRM service } \\
\text { providers provide direction and business } \\
\text { perspective to the CIO. }\end{array}$ & $\begin{array}{l}\text { Establish an IRM Advisory Committee } \\
\text { made up of knowledgeable representatives } \\
\text { from key ORP organizations and the major } \\
\text { IRM service providers to provide direction } \\
\text { and business perspective to the CIO. } \\
\text { Develop and implement IRM Advisory } \\
\text { Committee processes. } \\
\text { Communicate how the committee operates } \\
\text { with emphasis on enabling versus barrier } \\
\text { behaviors. }\end{array}$ \\
\hline $\begin{array}{l}\text { An IRM design authority reviews and } \\
\text { approves major information and } \\
\text { information resource-related activities } \\
\text { designs. }\end{array}$ & $\begin{array}{l}\text { Establish a design authority under the IRM } \\
\text { organization. The design authority has } \\
\text { responsibility for approving information- } \\
\text { and information resource-related design } \\
\text { and implementation activities. The design } \\
\text { authority's main objective is to ensure that } \\
\text { work adheres to the information }\end{array}$ \\
\hline
\end{tabular}




\section{RPP - 6212, Rev 1}

\begin{tabular}{|c|c|}
\hline Target & Proposal \\
\hline & architecture. \\
\hline $\begin{array}{l}\text { An IRM Configuration Control Board } \\
\text { reviews and approves changes to major } \\
\text { information and information resource- } \\
\text { related activities. }\end{array}$ & $\begin{array}{l}\text { Establish an IRM Configuration Control } \\
\text { Board that reviews and approves changes } \\
\text { to major information- and information } \\
\text { resource-related activities. }\end{array}$ \\
\hline $\begin{array}{l}\text { An IRM Program Review Board reviews } \\
\text { proposed an ongoing information- and } \\
\text { information resource-related activities from } \\
\text { a project perspective (i.e., cost, schedule, } \\
\text { and issues). }\end{array}$ & $\begin{array}{l}\text { Establish a Program Review Board that } \\
\text { reviews major information- and } \\
\text { information resource activities from a } \\
\text { project perspective. }\end{array}$ \\
\hline $\begin{array}{l}\text { An IRM Data Administration Council } \\
\text { reviews, approves, and establishes CHG- } \\
\text { wide data naming standards and guidelines. } \\
\text { The council will own and maintain the } \\
\text { CHG data dictionary. }\end{array}$ & $\begin{array}{l}\text { Establish a Data Administration Council } \\
\text { that reviews, approves, and establishes } \\
\text { CHG-wide data naming standards and } \\
\text { guidelines. The council will also own and } \\
\text { maintain the CHG data dictionary. }\end{array}$ \\
\hline $\begin{array}{l}\text { CHG information and information } \\
\text { resource-related activities adhere to a } \\
\text { coherent and practical set of IRM policies, } \\
\text { standards, guidelines, and procedures. }\end{array}$ & $\begin{array}{l}\text { Analyze the Site Requirements } \\
\text { Identification Documents (SRID) for the } \\
\text { ability to trace to CHG requirements and, } \\
\text { where appropriate, challenge SRID } \\
\text { requirements or interpretation of } \\
\text { requirements for the CHG mission. } \\
\text { Analyze existing Hanford Site policies and } \\
\text { procedures for the ability to trace to CHG } \\
\text { requirements and, where appropriate, } \\
\text { challenge HNF document requirements or } \\
\text { interpretation of requirements for the CHG } \\
\text { mission. } \\
\text { Establish the CHG baseline for required } \\
\text { practices, policies, procedures, and } \\
\text { standards. }\end{array}$ \\
\hline
\end{tabular}




\section{RPP - 6212, Rev 1}

\subsubsection{Budgeting Processes}

Budgets do not always provide for required IRM development and support personnel.

A definition of what constitutes "IRM" work is not clear. Work that should be classified, as IRM work is not accounted as such.

The CHG budget process has been shown to be inadequate for the following reasons:

- Budget planning is at the cost-account level, not the line organization level.

- Budget is on an annual cycle, and a majority of the participants do not have their required budget information until just before the new budget is due.

- DOE-required budget cuts are made to an accepted budget baseline within the first quarter of the new fiscal year.

- Most cost account managers do not fully understand the budget guidelines, policies, standards, and procedures to procure IRM products and/or services.

The following targets and proposals are for the information architecture work process budgeting processes component.

\begin{tabular}{||l|l||}
\hline \multicolumn{1}{|c|}{ Target } & \multicolumn{1}{|c||}{ Proposal } \\
\hline $\begin{array}{l}\text { A clear definition of what constitutes IRM } \\
\text { (information and information resource- } \\
\text { related activities) is clear to planning and } \\
\text { budgeting personnel so this type of work } \\
\text { can be accurately accounted for. }\end{array}$ & $\begin{array}{l}\text { The IRM organization will clearly define } \\
\text { what type of work should be considered } \\
\text { IRM work and make this definition known } \\
\text { to the planning and budgeting personnel. }\end{array}$ \\
\hline $\begin{array}{l}\text { The IRM budget process begins at the line } \\
\text { organization. }\end{array}$ & $\begin{array}{l}\text { IRM CIO staff assists line organizations in } \\
\text { preparing budgets. }\end{array}$ \\
\hline $\begin{array}{l}\text { Budgets are developed to a comprehensive } \\
\text { set of policies and procedures. }\end{array}$ & $\begin{array}{l}\text { Develop and implement a comprehensive } \\
\text { set of policies and procedures for } \\
\text { developing budgets. }\end{array}$ \\
\hline $\begin{array}{l}\text { The information- and information resource- } \\
\text { related budget dollars are under the control } \\
\text { of IRM and are allocated by a team } \\
\text { consisting of the IRM CIO and the } \\
\text { individuals assigned as a CHG } \\
\text { organization's single point of authority for }\end{array}$ & $\begin{array}{l}\text { The CIO partners with the CFO and } \\
\text { Program Budget Office to ensure that } \\
\text { information technology investments are } \\
\text { integrated into the budget process and that } \\
\text { development and submission of crosscut } \\
\text { budget information are coordinated. }\end{array}$ \\
\hline
\end{tabular}


RPP - 6212, Rev 1

\begin{tabular}{||l|l||}
\hline \multicolumn{1}{|c|}{ Target } & \multicolumn{1}{|c||}{ Proposal } \\
\hline $\begin{array}{l}\text { information- and information resource- } \\
\text { related activities. }\end{array}$ & \\
\hline $\begin{array}{l}\text { Cost account managers fully understand } \\
\text { IRM budget policies and procedures }\end{array}$ & $\begin{array}{l}\text { Train cost account managers on IRM } \\
\text { budget policies and procedures. }\end{array}$ \\
\hline
\end{tabular}

\subsubsection{IRM Procurement Products and Services Processes}

CHG has identified multiple design authorities related to the acquisition and implementation of IRM services, tool, etc. Many IRM technology purchases such as desktop PCs are made using P-cards. The PHMC CIO's office is responsible for the P-card purchase process. Many items must be on an approved list or an exception must be made to the CIO's office.

Most desktop software is covered by a single Site license. Most desktop software is available at the user's desktop from the network via a simple download procedure.

Procedures exist to allow users to download "freeware" and "shareware" from the Internet.

IRM-related labor services can be procured through service contracts. In some instances, a primary service provider is selected and given an exclusive first right of refusal contract. In other instances, a vendor is selected who meets the qualifications stated in the contract.

The following targets and proposals are for the information architecture work process IRM procurement products and service processes component.

\begin{tabular}{||l|l||}
\hline \multicolumn{1}{|c|}{ Target } & \multicolumn{1}{|c|}{ Proposal } \\
\hline $\begin{array}{l}\text { The CHG CIO is responsible for TFC } \\
\text { procurements of the IRM products and } \\
\text { services. }\end{array}$ & $\begin{array}{l}\text { Establish the CHG CIO as the manger } \\
\text { responsible for CHG procurements for } \\
\text { IRM products and services. }\end{array}$ \\
\hline $\begin{array}{l}\text { A set of policies and procedures is } \\
\text { available to the workforce that clearly } \\
\text { explains the process for procuring IRM } \\
\text { related products and services. Those who } \\
\text { need to review and approve the } \\
\text { procurement are clearly identified. }\end{array}$ & $\begin{array}{l}\text { Develop the policies and procedures to } \\
\text { support the procurement process and } \\
\text { identify the approval levels for each type of } \\
\text { procurement. Make the workforce aware } \\
\text { of these policies and procedures and } \\
\text { provide easy access to the same. }\end{array}$ \\
\hline
\end{tabular}




\section{River Protection Project - Organizations}

The following list describes the new organizations associated with the River Protection Project and the River Protection Project activities.

- CH2M HILL Hanford Group, Inc. Information Resource Management - is a functional organization that provides information resource management leadership and direction for $\mathrm{CHG}$, and when directed by the ORP.

- Information Resource Management: IRM is a functional organization that provides information resource management leadership and direction for the Tank Farm Contractor CH2M HILL Hanford Group, Inc. CHG's direction is to perform the IRM function as a CHG chartered responsibility. However, and if directed by ORP, the contents of this Charter can be applied to IRM as an Office of River Protection support organization.

- Office of River Protection: The Congress of the United States established the Office of River Protection (ORP) in 1998, as a Field Office, separate from the U.S. Department of Energy, Richland Operations Field Office. The Office of River Protection reports directly to the Department of Energy Assistant Secretary for Environmental Management and is charged with managing the Department of Energy's largest and most complex environmental cleanup project - the storage, retrieval, treatment, and disposal of Hanford Site tank waste.

- Waste Treatment Contractor: The Waste Treatment Contractor (PC) is a primary contractor for the River Protection Project and is responsible for design, construction, and operation of the waste immobilization facility.

- Program Office: The Office of River Protection created the Program Office (PGO) to perform the fundamental activity of strategic planning, baseline/change control, and long range planning. In addition the PGO contains the ORP-CIO, whose job is to ensure the ORP and DOE-directed information and information-related requirements and deliverables are met in a timely and cost-effective manner.

- River Protection Project: ORP manages the River Protection Project (RPP) to store, retrieve, treat, and dispose of the Hanford Site's tank waste. ORP has selected a Tank Farm Contractor and a Waste Treatment Contractor to perform the work.

- Tank Farm Contractor: The Tank Farm Contractor (TFC) is a primary contractor for the River Protection Project and performs the planning and operations necessary for tank waste storage, retrieval, treatment, and final waste storage and disposal. CH2M HILL Hanford Group, Inc. (CHG) is the current TFC. 